\title{
Analisis Fisika-Kimia Air Sumur Di Tempat Pembuangan Akhir Sumompo Kecamatan Tuminting Manado
}

\author{
Martin Aprilino Tambunan a*, Jemmy Abidjulu a, Audy Wuntu a \\ aJurusan Kimia, FMIPA, Unsrat, Manado
}

\begin{tabular}{l} 
KA TA KUNCI \\
\hline analisis fisika-kimia \\
air sumur \\
TPA Sumompo
\end{tabular}

\begin{abstract}
A B S T R A K
Telah dilakukan penelitian tentang kualitas fisika-kimia air sumur di tempat pembuangan akhir sampah (TPA) kecamatan Tuminting, Manado secara kualitatif dan kuantitatif. Kajian yang dilakukan meliputi parameter fisika yaitu penentuan $\mathrm{pH}$, bau, rasa, warna, kekeruhan dan total padatan terlarut (TDT) serta parameter kimia yaitu penentuan nitrat, nitrit, klorida, sulfat, besi dan mangan. Berdasarkan hasil pengujian parameter fisika pada 4 titik pengambilan air ada beberapa titik pengambilan sampel yang tidak sesuai dengan syarat baku mutu kualitas air yaitu tidak berbau dan berasa serta memiliki rentang $\mathrm{pH}$ 6,5-9,2 dan memiliki nilai maksimal untuk warna 50, kekeruhan 25, dan TDT 1500. Begitu juga untuk parameter kimia ada beberapa titik pengambilan sampel yang tidak sesuai dengan syarat baku mutu kualitas air yaitu memiliki nilai maksimal untuk klorida $600 \mathrm{mg} / \mathrm{L}$, nitrat $10 \mathrm{mg} / \mathrm{L}$, nitrit $1 \mathrm{mg} / \mathrm{L}$, besi $1 \mathrm{mg} / \mathrm{L}$, mangan $0,5 \mathrm{~m} / \mathrm{L}$ dan sulfat $400 \mathrm{mg} / \mathrm{L}$.

A B S T R A C T

$A$ research on the physico-chemical quality of the well water in the landfill (TPA) district Tuminting, Manado has been done. The study included physical parameters, namely $\mathrm{pH}$, odor, taste, color, turbidity and total dissolved solids (TDS) and chemical parameters, namely nitrate, nitrite, chloride, sulphate, iron and manganese. Among the four sampling sites, some sites did not meet the water quality standard based on some physical parameters, those are odorless and tasteless, $\mathrm{pH}$ range of 6.5 to 9.2 and maximum value of 50 for color, 25 for turbidity, and 1500 for TDS. Likewise, for chemical parameters, several sampling points are not in accordance with the terms of water quality standard, those are maximum value of $600 \mathrm{mg} / \mathrm{L}$ for chlorides, $10 \mathrm{mg} / \mathrm{L}$ for nitrate, $1 \mathrm{mg} / \mathrm{L}$ for nitrite, 1 $\mathrm{mg} / \mathrm{L}$ for iron, $0.5 \mathrm{~m} / \mathrm{L}$ for manganese and $400 \mathrm{mg} / \mathrm{L}$ for sulphate.
\end{abstract}

KEYW OR D S

physico-chemical analysis

well water

landfill Sumompo

TERSEDIA ONLINE

29 juli 2015

1. Pendahuluan

Pencemaran terjadi diberbagi tempat, termasuk di lingkungan kita berada. Kecenderungan pencemaran terjadi sejak perang dunia ke dua yang mengarah pada dua hal yaitu pembuangan senyawa kimia tertentu yang makin meningkat, terutama akibat kegiatan industri dan transportasi dan akibat penggunaan bahan-bahan berbahaya oleh manusia. Kegiatan industri, transportasi, dan aktivitas manusia yang banyak mengeluarkan bahan pencemaran seringkali merusak keadaan lingkungan, salah satunya adalah air (Achmad, 2004).

Air merupakan senyawa kimia yang sangat penting bagi kehidupan manusia dan mahluk hidup lainnya dan fungsinya bagi kehidupan tidak akan dapat digantikan dengan senyawa lainnya (Achmad, 2004).

Air yang tidak berbau dan berwarna merupakan air yang baik, sebaliknya air yang mempunyai warna tertentu pasti mengandung bahan kimia. Demikian pula dengan bau, bila air

*Corresponding author: Jurusan Kimia FMIPA UNSRAT, Jl. Kampus Unsrat, Manado, Indonesia 95115; Email address: martintambunan@gmail.com Published by FMIPA UNSRAT (2015) 
berbau biasanya mengandung bahan-bahan organik (SuyaNta, 2002). Menurut Freedman dalam Suyanta (2002), kualitas air ditentukan oleh kandungan ion logam dan non logam dalam air, seperti logamlogam perak (Ag), kadmium (Cd), krom (Cr), kobalt (Co), tembaga (Cu), besi (Fe), merkuri (Hg), molibdenum (Mo), nikel (Ni), timbal (Pb), timah (Sn), Seng ( $\mathrm{Zn}$ ), Aluminium (Al), arsen (As) dan selenium (Se). Adanya anion-anion seperti klorida (Cl-), sulfat (SO42-) dan nitrat (NO3-) juga dapat menyebabkan rendahnya kualitas air. Selain itu kualitas air juga ditentukan oleh beberapa faktor fisik seperti temperatur, rasa, dan total padatan terlarut (TDT).

Di kota Manado, lokasi pembuangan sampah terletak di daerah Sumompo Kecamatan Tuminting. Meskipun daerah ini merupakan Tempat Pembuangan Akhir (TPA) sampah, namun disekitar daerah ini terdapat pemukiman yang dipadati penduduk. Sebagian penduduk di sekitar TPA menggunakan sumur sebagai sumber air bersih untuk minum, makan, mandi dan mencuci. Dilihat dari keadaan dan letak sumur maka perlu diadakan penelitian untuk mengetahui kualitas air di sekitar TPA Sumompo Kecamatan Tuminting Kota Manado berdasarkan PERMENKES No. 416 tahun 1990.

\section{Material dan Metode}

\subsection{Material}

Peralatan yang digunakan dalam penelitian ini adalah spektrofotometer Uv-Vis, ICPE, alat uji TDT meter, pH meter, oven, neraca analitik, turbidimeter, peralatan titrasi dan peralatan gelas kimia.

Bahan-bahan yang digunakan dalam penelitian ini adalah sampel air sumur, aquades, larutan aquades asam nitrat, asam askorbat, larutan indicator dikromat 5\%, larutan $\mathrm{AgNO}_{3}$.

Sumur tempat pengambilan sampel pada titiktitik 1, 2 dan 3 berjarak kurang lebih $50 \mathrm{~m}$ arah utara dari lokasi tempat pembuangan akhir (TPA) dan letaknya lebih rendah dari lokasi TPA. Sedangkan sumur tempat pengambilan sampel pada titik 4 terletak kurang lebih $100 \mathrm{~m}$ arah selatan lokasi TPA dan letakknya lebih tinggi dari lokasi TPA.

\subsection{Prosedur \\ Penentuan $\mathrm{pH}$}

Ke dalam gelas piala $150 \mathrm{~mL}$ dimasukkan 100 $\mathrm{mL}$ sampel kemudian dicelupkan elektroda dari $\mathrm{pH}$ meter, dan dibaca nilai $\mathrm{pH}$ pada alat.

\section{Bau dan Rasa}

Bau dan rasa dilakukan dilakukan di Laboratorium Baristand Industri Manado. Pengujian dilakukan oleh 5 responden untuk mencium bau dan mengecap sampel air sumur tersebut kemudian memberikan pendapat mengenai bau (berbau atau tidak berbau) dan rasa (berasa atau tidak berasa).
Warna

Sampel dikocok kemudian dimasukkan kedalam kuvet, kemudian dibaca pada alat spektrofotometer Uv-Vis.

\section{Kekeruhan}

Sampel dihomogenkan dengan cara dikocok kemudian dimasukan dalam kuvet. Kuvet yang berisi sampel dianalisis dengan alat turbidimeter dan dibaca nilainya.

\section{Total Padatan Terlarut (TDT)}

Sampel air sebanyak $100 \mathrm{~mL}$ dimasukkan kedalam gelas piala $150 \mathrm{~mL}$ kemudian dicelupkan elektroda yang ada pada TDT meter dan kemudian dibaca konsentrasinya

\section{Penentuan Nitrat}

Penentuan nitrat dilakukan dengan metode reduksi kadmium. Dibuat deret standard larutan pembanding yang diketahui nilai konsentrasinya dan kedalam botol sampel dimasukkan $25 \mathrm{~mL}$ sampel air kemudian di tambahkan reagen NitraVer 5 Nitrate lalu dikocok selama 1 menit dan didiamkan selama 5 menit, kemudian dianalisis menggunakkan spektrofotometer Uv-Vis pada panjang gelombang $500 \mathrm{~nm}$. Mula-mula dimasukkan botol blanko dan bacaan pada alat dan alat diset pada angka nol. Selanjutnya botol blanko digantikan dengan botol deret standard kemudian dilanjutkan dengan botol sampel dan konsentrasi nitrat dalam $\mathrm{mg} / \mathrm{L}$ ditunjukkan langsung pada alat.

\section{Penentuan Nitrit}

Penentuan nitrit dilakukan dengan metode ferrosulfat. Pada botol sampel dimasukan $10 \mathrm{~mL}$ sampel air kemudian ditambahkan reagen NitriVer 2 Nitrite lalu dikocok sampai larut dan didiamkan selama 10 menit. Pada botol blanko dimasukkan 10 $\mathrm{mL}$ sampel. Konsentrasi nitrit dianalisis dengan spektrofotometer Uv-Vis pada panjang gelombang $585 \mathrm{~nm}$. Mula-mula dimasukkan botol blanko kemudian diset pada nilai nol dan larutan deret standar serta larutan sampel, kemudian konsentrasi nitrit dalam $\mathrm{mg} / \mathrm{L}$ ditunjukkan langsung pada alat.

\section{Penentuan Klorida}

Penetuan kadar klorida dilakukan dengan metode argentometri. Sampel air sebnayak $50 \mathrm{~mL}$ dimasukkan kedalam erlenmeyer $250 \mathrm{~mL}$, kemudian ditambahkan $0,5 \mathrm{~mL}$ larutan dikromat 5 $\%$ dan dikocok. Larutan ini kemudian dititrasi dengan larutan $\mathrm{AgNO}_{3}$ 0,0141 $\mathrm{N}$ sampai terbentuk warna merah kecoklat-coklatan. Banyak volume $\mathrm{AgNO}_{3}$ yang digunakan pada buret dicatat dan perlakuan ini dilakukan juga pada larutan blanko bebas klorida, kemudian dilakukan perhitungan kadar klorida sebagai berikut (Anonim, 1994).

\section{Penentuan Sulfat}

Penentuan sulfat dilakukan dengan metode Sulva Ver 4. Sampel air dimasukkan ke dalam erlenmeyer sebanyak $25 \mathrm{~mL}$, kemudian diatambahkan reagen Sulva Ver 4 lalu dikocok dan didiamkan selama 5 menit, kemudian dimasukkan 
kedalam kuvet. Pada blanko dan deret standard ditambahkan juga reagen SulvaVer 4 ini dan dikocok, kemudian dianlisa dengan menggunakan spektrofotometer Uv-Vis pada panjang gelombang $450 \mathrm{~nm}$. Mula-mula larutan blanko dimasukkan kemudian disetel pada angka nol. Selanjutnya dimasukkan larutan deret standard dan dilanjukan dengan larutan sampel. Konsentrasi sulfat dalam $\mathrm{mg} / \mathrm{L}$ ditunjukkan pada alat.

\section{Penentuan Besi dan Mangan}

Penentuan besi dan mangan dilakukan dengan cara pengasaman sampel dengan ditambahkannya larutan asam nitrat pada sampel dan kemudian diasring dengan kertas saring 0,45 mikron dan dilakukan pembacaan menggunakan alat ICPE, nilai konsentrasi besi dan mangan dalam satuan $\mathrm{mg} / \mathrm{L}$ ditunjukkan pada alat.

\section{Hasil dan Pembahasan}

Sampel air dari empat sumur berbeda di sekitar TPA Sumompo di analisis untuk parameter fisika dan kimia dengan menggunakan metode analisis standar untuk setiap parameternya. Hasil analisis ditunjukkan pada Tabel 1. Pengolahan data didasarkan Standar Baku Mutu Kualitas Air Bersih dalam Peraturan Menteri Kesehatan Republik Indonesia Nomor. 416/MENKES/PER/ IX/1990.

Tabel 1. Data hasil pengujian fisika, kimia dan biologi sumber air di sekitar TPA Sumompo

\begin{tabular}{|c|c|c|c|c|c|c|c|}
\hline \multirow{2}{*}{ No. } & \multirow{2}{*}{ Parameter } & \multirow{2}{*}{ Unit } & \multirow{2}{*}{ Syarat } & \multicolumn{4}{|c|}{ Sampel } \\
\hline & & & & Titik I & Titik II & Titik III & Titik IV \\
\hline 1 & Rasa & - & Tidak berasa & $\begin{array}{l}\text { Tidak } \\
\text { berasa }\end{array}$ & $\begin{array}{l}\text { Tidak } \\
\text { berasa }\end{array}$ & $\begin{array}{l}\text { Tidak } \\
\text { berasa }\end{array}$ & $\begin{array}{l}\text { Tidak } \\
\text { berasa }\end{array}$ \\
\hline 2 & Bau & - & Tidak berbau & $\begin{array}{l}\text { Tidak } \\
\text { berbau }\end{array}$ & $\begin{array}{l}\text { Tidak } \\
\text { berbau }\end{array}$ & $\begin{array}{l}\text { Tidak } \\
\text { berbau }\end{array}$ & $\begin{array}{l}\text { Tidak } \\
\text { berbau }\end{array}$ \\
\hline 3 & Warna & NTU & Max 50 & 35 & 53 & 61 & 24 \\
\hline 4 & Kekeruhan & NTU & Max 25 & 22 & 18 & 20 & 7 \\
\hline 5 & TDT & $\mathrm{mg} / \mathrm{L}$ & Max 1500 & 195 & 102 & 40 & 25 \\
\hline 6 & $\mathrm{pH}$ & - & $6,5-9,2$ & 6,3 & 7,1 & 6,0 & 7,8 \\
\hline 7 & Klorida & $\mathrm{mg} / \mathrm{L}$ & Max 600 & 30,45 & 45,00 & 29,76 & 32,15 \\
\hline 8 & Nitrat & $\mathrm{mg} / \mathrm{L}$ & Max 10 & 9,1 & 2,8 & 0,90 & 8,3 \\
\hline 9 & Nitrit & $\mathrm{mg} / \mathrm{L}$ & $\operatorname{Max} 1,00$ & 0,03 & 0,03 & 0,04 & 0,03 \\
\hline 10 & Besi & $\mathrm{mg} / \mathrm{L}$ & $\operatorname{Max} 1,00$ & 0,827 & 0,303 & 0,347 & 0,401 \\
\hline 11 & Mangan & $\mathrm{mg} / \mathrm{L}$ & Max 0,50 & 0,001 & 0,001 & 0,001 & 0,001 \\
\hline 12 & Sulfat & $\mathrm{mg} / \mathrm{L}$ & Max 400 & 25 & 17 & 16 & 60 \\
\hline
\end{tabular}

Hasil analisis parameter pada Tabel 1 untuk rasa, bau, TDT dan kekeruhan pada sumur di keempat titik lokasi pengambilan memperlihatkan nilai air yang masih layak menurut Standar Baku Mutu Kualitas Air Bersih Permenkes Nomor. 416 tahun 1990, namun untuk parameter uji warna pada pada lokasi 2 dan 3 memiliki hasil analisis yang melebihi syarat ambang batas untuk air bersih, hal ini dimungkinkan karena lokasi sumber air pada lingkungan yang terbuka sehingga banyaknya kotoran debu dan dedauan dari pohon sekitar serta guguran bahan organik yang mengandung tannin, humus dan lignin yang mengkontaminasi air (Sutrisno dan Sucipto, 1987).

Hasil analisis untuk kadar keasaman air $(\mathrm{pH})$ terdapat dua lokasi yang melewati syarat ambang batas Kualitas Air Bersih Permenkes No. 416 tahun 1990, yaitu pada lokasi 1 dan 4 dengan nilai 6,3 dan 6,0 dimana kualitas air yang sebagai syarat berkisar 6,5-9,2. Hal ini disebabkan lingkungan sekitar sumber air tersebut ditanami tumbuhan yang diberi pupuk.

Hasil pengujian untuk senyawa nitrat pada sumber mata air pada titik 4 yaitu $8,3 \mathrm{mg} / \mathrm{L}$ dan hasil pengujian tersebut masih dalam batasan Baku Mutu Kualitas Air Bersih yaitu 10 mg/L. Tingginya kandungan nitrat pada titik 1 dan 4 dimungkinkan dari lingkungan yang banyak aktivitas peternakan dan hewan-hewan yang berkeliaran disekitar sumber air, dimana nitrat dapat terbentuk oleh aktivitas mikroorganisme yang menyebabkan pembusukan bahan organik.

Hasil pengujian dari keempat sumber air masih memenuhi syarat Baku Mutu Kualitas Air Bersih dengan kisaran nilai 0,03-0,04 mg/Lsesuai Permenkes No. 416 tahun 1990, dengan batas maksimum adalah $1 \mathrm{mg} / \mathrm{L}$. Pada penentuan kadar nitrit secara kimia melalui proses diazotisasi, dimana nitrit yang bereaksi dengan asam sulfanilat membentuk garam diazonium. Dan garam yang terbentuk disebabkan garam kromatropik, dimana senyawa nitrit ini memiliki tampilan warna jingga, dan warna ini dapat dibaca pada panjang gelombang $585 \mathrm{~nm}$ pada alat spektrofotometer (HACH Company, 2002).

Hasil pengujian pada parameter klorida menunjukkan bahwa kualitas air sumber di daerah tempat pembuangan sampah di Sumompo ini masih dibawah ambang batas atas Kualitas Air Bersih 
Permenkes No. 416 tahun 1990, dengan kualitas air sekitar daerah $29,76-45,20 \mathrm{mg} / \mathrm{L}$, hasil terendah meningkat jika dibandingkan penelitian yang dilakukan Pakasi (2007) namun lebih rendah nilai klorida dari nilai tertinggi pada penelitian Yurike (2010).

Hasil pengujian dari keempat sumber air yang ada menunjukkan bahwa kadar sulfat pada sumber air masih dibawah batas syarat Kualitas Air Bersih Permenkes No. 416 Tahun 1990, dengan nilai kisaran $15-60 \mathrm{mg} / \mathrm{L}$, namun kondisi ini meningkat dari penelitian sebelumnya yang dilakukan Pakasi (2007) dan Yurike (2010) hal ini disebabkan semakin banyaknya timbunan sampah yang organik yang mengakibatkan pertumbuhan bakteri anaerobik dan pelarutan mineral sulfat seperti gypsum dan pupuk dari senyawa sulfur dalam air hujan akibat gas buang industri.

Hasil pengujian dari keempat sumber air yang ada menunjukkan bahwa kadar yang meningkat dari penelitian Pakasi (2007) dan Yurike (2010) dimungkinkan karena semakin banyaknya sampah yang berupa kaleng pada timbunannya, dengan sumber air yang memiliki kadar 0,303-0,827 mg/L ini menyatakan bahwa penigkatan kadar besi sangat berbahaya untuk diwaktu yang akan datang, walaupun nilai kadar besi di keempat sumber air ini masih dibawah syarat Kualitas Air Bersih Permenkes No. 416 Tahun 1990.

Hasil pengujian dari keempat sumber air yang ada menunjukkan bahwa kadar mangan tidaklah terjadi banyak perbuahan dari penelitian yang dilakukan Pakasi (2007) dan Yurike (2010), karena nilai mangan pada bulan Juni 2015 ini masih berkisaran 0,001-0,0055 mg/L. Dan masih di bawah syarat Kualitas Air Bersih Permenkes No. 416 Tahun 1990.

\section{Kesimpulan}

Kualitas air bersih dari sumber air di sekitar tempat pembuangan akhir (TPA) di daerah Sumompo Kecamatan Tuminting Kota Manado, masih secara keseluruhan memenuhi Standar Baku Kualitas Air Bersih berdasarkan Permenkes Nomor 416/MENKES/PER/IX/1990. Untuk parameterparameter kimia, seperti klorida, nitrat, nitrit, besi, mangan dan sulfat, dan untuk parameter $\mathrm{pH}$ ada dua titik memiliki nilai lebih rendah dari standar, sedangkan untuk parameter fisika pada warna ada dua titik dengan nilai lebih tinggi dari standar baku kualitas air bersih.

\section{Daftar Pustaka}

Achmad, R. 2004. Kimia Lingkungan. Andi, Yogyakarta.

HACH Company. 2002. DRL 2400 Spectrofotometer Procedural Manual. HACH Company. Colorado.

HACH Company. 2008. Water Analysis Handbook (5 $5^{\text {th }}$ ed.). HACH Company. Colorado.

MENLH. 2001. Peraturan Pemerintah Republik Indonesia No. 82 tahun 2001 Tentang Pengelolaan Kualitas Air dan Pengendalian Pencemaran Air. Jakarta.

Pandia, S., Husia, dan Z. Masyaitha. Kimia Lingkungan. Proyek Pengembangan Pusat Studi lingkungan (PP-PSL), Jakarta.

PERMENKES. 1990. Peraturan Mentri Kesehatan No. 416 Tahun 1990 Tentang Syarat Mutu Kualitas Air Bersih. Jakarta.

Suyanta. 2002. Analisis Kualitas Air Sumur di Daerah Aliran Sungai Code, Yogyakarta. Jurnal Kimia Lingkungan. 4 (1): 55-5. 